I. O. Lychenko

Educational-Scientific Institute of Law and Psychology

Lviv Polytechnic National University,

D.Sc. (Law), Associate Professor

lychenko7@gmail.com

I. M. Zharovska

Educational-Scientific Institute of Law and Psychology

Lviv Polytechnic National University,

D.Sc. (Law), Associate Professor

irazhar@ukr.net

\title{
ECONOMIC AND LEGAL PRINCIPLES OF PROTECTION OF PROPERTY RIGHTS IN THE AREAS OF CONDUCTING UNITED FORCES OPERATION
}

\author{
(C) Lychenko I. O., Zharovska I. M., 2019
}

The article is devoted to the economic and legal principles of protection of property rights in areas of operation of the united forces in Ukraine. Particular attention is focused on modern economic and legal challenges and threats, factors of anthropogenic influence on the sphere of property and ways of their overcoming. The article clarifies the problems of implementation of economic and legal measures to guarantee the citizens of Ukraine the right to own, use and dispose of property, factors of creating an effective economic and legal model of the reintegration of territories that are or were occupied, ensuring the proper living conditions of citizens who suffered as a result of conducting united forces operations in Ukraine.

Keywords: property; property rights; protection; economic and legal principles of protection; areas of conducting united forces operation.

И. О. Лыченко, И. М. Жаровская

\section{ЭКОНОМИКО-ПРАВОВЫЕ ОСНОВЫ ЗАЩИТЫ ПРАВА СОБСТВЕННОСТИ ГРАЖДАН УКРАИНЫ В РАЙОНАХ ПРОВЕДЕНИЯ ОПЕРАЦИИ ОБЬЕДИНЕННЫХ СИЛ}

В статье определены экономико-правовые основы защиты права собственности в районах проведения операции объединенных сил в Украине. Особое внимание сосредоточено на современных экономико-правовых вызовах и угрозах, факторах антропогенного воздействия на сферу собственности и способах их преодоления. В статье определены проблемы реализации экономико-правовых мер по обеспечению гражданам Украины права владения, пользования и распоряжения имуществом, факторы создания эффективной экономико-правовой модели реинтеграции территорий, которые являются или были оккупированными, обеспечения надлежащих условий жизнедеятельности граждан, пострадавших в результате проведения операции объединенных сил в Украине.

Ключевые слова: собственность; право собственности; защита; экономикоправовые основы защиты; районы проведения операции объединенных сил. 
Навчально-науковий інститут права та психології Національного університету «Львівська політехніка», доктор юридичних наук, доцент, професор кафедри цивільного права та процесу

I. М. Жаровська

Навчально-науковий інститут права та психології Національного університету «Львівська політехніка», доктор юридичних наук, професор кафедри теорії та філософії права

\section{ЕКОНОМІКО-ПРАВОВІ ЗАСАДИ ЗАХИСТУ ПРАВА ВЛАСНОСТІ ГРОМАДЯН УКРАЇНИ В РАЙОНАХ ПРОВЕДЕННЯ ОПЕРАЦІї ОБ'СДНАНИХ СИЛ}

У статті визначено економіко-правові засади захисту права власності в районах проведення операції об'сднаних сил в Україні. Особливу увагу зосереджено на сучасних економіко-правових викликах та загрозах, чинниках антропогенного впливу на сферу власності та способах їхнього подолання. У статті з'ясовано проблеми реалізації економіко-правових заходів щодо гарантування громадянам України права володіння, користування та розпорядження майном, чинники створення ефективної економікоправової моделі реінтеграції територій, які є, або були окупованими, забезпечення належних умов життсдіяльності громадян, які постраждали внаслідок проведення операції об'сднаних сил в Україні.

Ключові слова: власність; право власності; захист; економіко-правові засади захисту; райони проведення операції об'сднаних сил.

Problem statement.The scientific substantiation of economic and legal factors influencing the protection of property rights, the formation of basic economic and legal principles of overcoming problems in this sphere and the formation of effective economic and legal guarantees of ownership, use and disposal of property are the foundation of creating the effective economic and legal model of reintegration assistance to areas that are, or have been occupied, ensuring the adequate conditions of life of citizens affected in these difficult socio-economic conditions, the preservation of their rights to possess, use and dispose of property. The research proves the relevance of new socio-economic challenges and threats in forming modern economic and legal principles of protection of property rights in the areas of conducting united forces operations, determining the priorities of the state policy concerning this question.

Brief Literature Review.An important theoretical basis of the research is publications dedicated to the development of democratic public institutions in conditions of war and armed conflicts. This question is discussed in the publication of Pierre Yared (2010) [3], Debraj Ray (2017) [4], Tanisha M. Fazal (2017) [5], Gregory D. Hess, Athanasios Orphanides (2001) [6].

The general problems of ensuring the protection of property rights have been the subject of scientific studies of famous economists and lawyers. Right of ownership and its protection were investigated by Francisco M. Gonzalez (2007) [7], Jordan J. S. (2006) [8], Hrynchuk (2001) [9], Halunko (2009) [10] and others. 
However, the authors of these publications did not take into account the emergence of new challenges and threats in the areas of conducting united forces operation, problems of the creation of the effective economic and legal model of reintegration assistance to areas that are, or have been occupied, lack of the proper conditions of life of the citizens affected in these difficult socio-economic circumstances. Only a comprehensive determination of economic and legal factors that affect the protection of property rights will define the ways of solving the existing problems in this area.

The purpose of the research is the analysis of modern economic and legal principles of protection of property rights in the areas of conducting united forces operation.

Results. In Ukraine during 2014-2017 a mass relocation of citizens from Donetsk and Luhansk oblasts in other regions and foreign countries took place. A significant number of these people moved to the countries of the European Union and applied to the immigration services in order to obtain the status of refugee. Many citizens applied for their recognition as internally displaced persons. On February 5, 2018, according to the data of the structural units of social protection of the population at regional public administrations and Kyiv City Public Administration, 1493057 migrants and 1218611 families from Donbas and Crimea were registered [11]. During 2014-2017 a large number of internally displaced persons were registered in the areas of Donetsk and Luhansk oblasts, which are under the control of Ukraine, and in Kyiv, and this dynamics continues for the future (Table 1). More than 239100 persons addressed to the government organizations of the European Union in order to recognize them as refugees [1]. The largest number of citizens of Ukraine applied to the state migration agencies of Germany, Italy, Poland, France, and Sweden (Table 2).

Table 1

Internally displaced persons of Donetsk and Luhansk oblasts that according to the Ministry of Social Policy were registered in other regions of Ukraine, 2017

\begin{tabular}{|c|c|c|}
\hline Oblast of registration & $\begin{array}{c}\text { The number of migrants from } \\
\text { Donetsk oblast }\end{array}$ & $\begin{array}{c}\text { The number of migrants from } \\
\text { Luhansk oblast }\end{array}$ \\
\hline 1 & 2 & 3 \\
\hline Vinnytsia & 6 & 2 \\
\hline Volyn & 12 & 108 \\
\hline Dnipropetrovsk & 420 & 371 \\
\hline Donetsk & 6023 & 24 \\
\hline Zhytomyr & 27 & 4 \\
\hline Zakarpattia & 10 & 0 \\
\hline Zaporizhia & 573 & 204 \\
\hline Ivano-Frankivsk & 0 & 14 \\
\hline Kyiv & 285 & 1879 \\
\hline Kirovohrad & 29 & 0 \\
\hline Luhansk & 100 & 27 \\
\hline Lviv & 0 & \\
\hline Mykolaiv & 42 & 29 \\
\hline & & 27 \\
\hline
\end{tabular}


Continuation of table 1

\begin{tabular}{|c|c|c|}
\hline 1 & 2 & 3 \\
\hline Odesa & 31 & 6 \\
\hline Poltava & 113 & 69 \\
\hline Rivne & 4 & 1 \\
\hline Sumy & 22 & 14 \\
\hline Ternopil & 5 & 3 \\
\hline Kharkiv & 872 & 873 \\
\hline Kherson & 54 & 19 \\
\hline Khmelnytskyi & 0 & 0 \\
\hline Cherkasy & 46 & 17 \\
\hline Chernivtsi & 0 & 0 \\
\hline Chernihiv & 0 & 0 \\
\hline the city of Kyiv & 1150 & 569 \\
\hline Totality & 9824 & 4305 \\
\hline
\end{tabular}

Source: Compiled by the authors according to[12]

Countries that have received the largest number of refugees

Table 2

from Donbas for the period from January 2014 to August 2017

\begin{tabular}{|c|c|}
\hline Country & The number of migrants \\
\hline Germany & 9616 \\
\hline Italy & 9319 \\
\hline Poland & 4278 \\
\hline France & 3459 \\
\hline Sweden & 3148 \\
\hline Totality & $\mathbf{9 8 2 4}$ \\
\hline
\end{tabular}

Source: Compiled by the author according to [13]

According to the results of conducting a public opinion poll (200 citizens of Ukraine who live in Donetsk oblast (100 persons) and Luhansk oblast (100 persons), $40 \%$ of respondents admitted that the basic economic and legal reason for migration is the improper protection of property rights. The same number of people (40\%) chose a threat to life and health as the main reason for migration. The interviewed persons attached much less importance to socio-economic conditions of life $(20 \%)$. The results ofconducting a public opinion poll showed that the most powerful economic and legal factors influencing the ownership in terms of united forces operation(UFO and ATO) are the hostilities (32\%) and the lack of the legislation on compensatory payments for destroyed and damaged dwelling, property expropriated in connection with the implementation of mobilization measures (24\%). Quite a lot of respondents $(22 \%)$ consider that the activities of the public administration concerning the protection of 
property rights in Donetsk and Luhansk oblasts are inefficient. Impossibility to profit from property in Donetsk and Luhansk oblasts in terms of UFO and ATO (12\%) and sudden decrease in the value of property in terms of hostilities (10\%) have the less significance (Table 3$)$.

Table 3

The results of conducting a public opinion poll of 200 Ukrainian citizens residing in Donetsk (100 persons) and Luhansk (100 persons) oblasts concerning economic and legal factors of influencing the ownership

\begin{tabular}{|c|c|c|}
\hline \multicolumn{3}{|c|}{$\begin{array}{c}\text { Question: } \\
\text { What economic and legal factors do affect the ownership in terms of UFO and ATO? }\end{array}$} \\
\hline Response & $\begin{array}{l}\text { The number of } \\
\text { persons who } \\
\text { have chosen the } \\
\text { response }\end{array}$ & $\begin{array}{l}\text { Percentage of } \\
\quad \text { selected } \\
\text { responses }(\%)\end{array}$ \\
\hline Hostilities that lead to the destruction of property & 64 & 32 \\
\hline $\begin{array}{l}\text { Impossibility to profit from property in Donetsk and Luhansk oblasts in } \\
\text { terms of ATO }\end{array}$ & 24 & 12 \\
\hline Sudden decrease in the value of property in terms of hostilities & 20 & 10 \\
\hline $\begin{array}{l}\text { Lack of the legislation on compensatory payments for destroyed and } \\
\text { damaged dwelling, property expropriated in connection with the } \\
\text { implementation of mobilization measures }\end{array}$ & 48 & 24 \\
\hline $\begin{array}{l}\text { Inefficiency of the activities of the public administration concerning } \\
\text { the protection of property rights in Donetsk and Luhansk oblasts }\end{array}$ & 44 & 22 \\
\hline
\end{tabular}

Source: Compiled by the authors

Loss of movable and immovable property in the areas of conducting united forces operationas a result of the hostilities, lack of the protection of property, which is located in the occupied part of Ukraine and at the «dividing line», where the implementation of transactions concerning the property is difficult, lack of a proper system of carrying out compensatory payments for destroyed, damaged housing, property expropriated in connection with the implementation of mobilization measures, mechanisms of compensation for lost dwelling, the cost of construction and acquisition of housing instead of destroyed ones are the significant factors reflecting the methodological problems of the protection of property rights in Ukraine. According to the rating of the 2017 International Property Rights Index, Ukraine has taken the $123^{\text {rd }}$ position among 127 countries [14].

The OSCE Special Monitoring Mission to Ukraine has repeatedly stressed on this problem. It was reported that the property of the civilian population from both sides of the line of collision was damaged as a result of the numerous cases of mortar and artillery shelling. According to the thematic report of the OSCE Special Monitoring Mission to Ukraine «Difficult situation of the civilian population affected by the conflict in the East of Ukraine» 2017, the total amount of losses for the destroyed or damaged property is 1884.4 million UAN, the total number of damaged or destroyed facilities -9029, including: 838 houses of communal property, 24 - building and loan associations, 42 - condominiums and 8125 private dwelling houses. In Luhansk oblast the total amount of losses for the destroyed or damaged property is 519.8 million UAN, the total number of damaged or destroyed facilities - 6857, including: the 
damaged objects - 6310 (994 apartments and 5316 houses); the destroyed objects - 547 (129 apartments and 418 houses) [15].
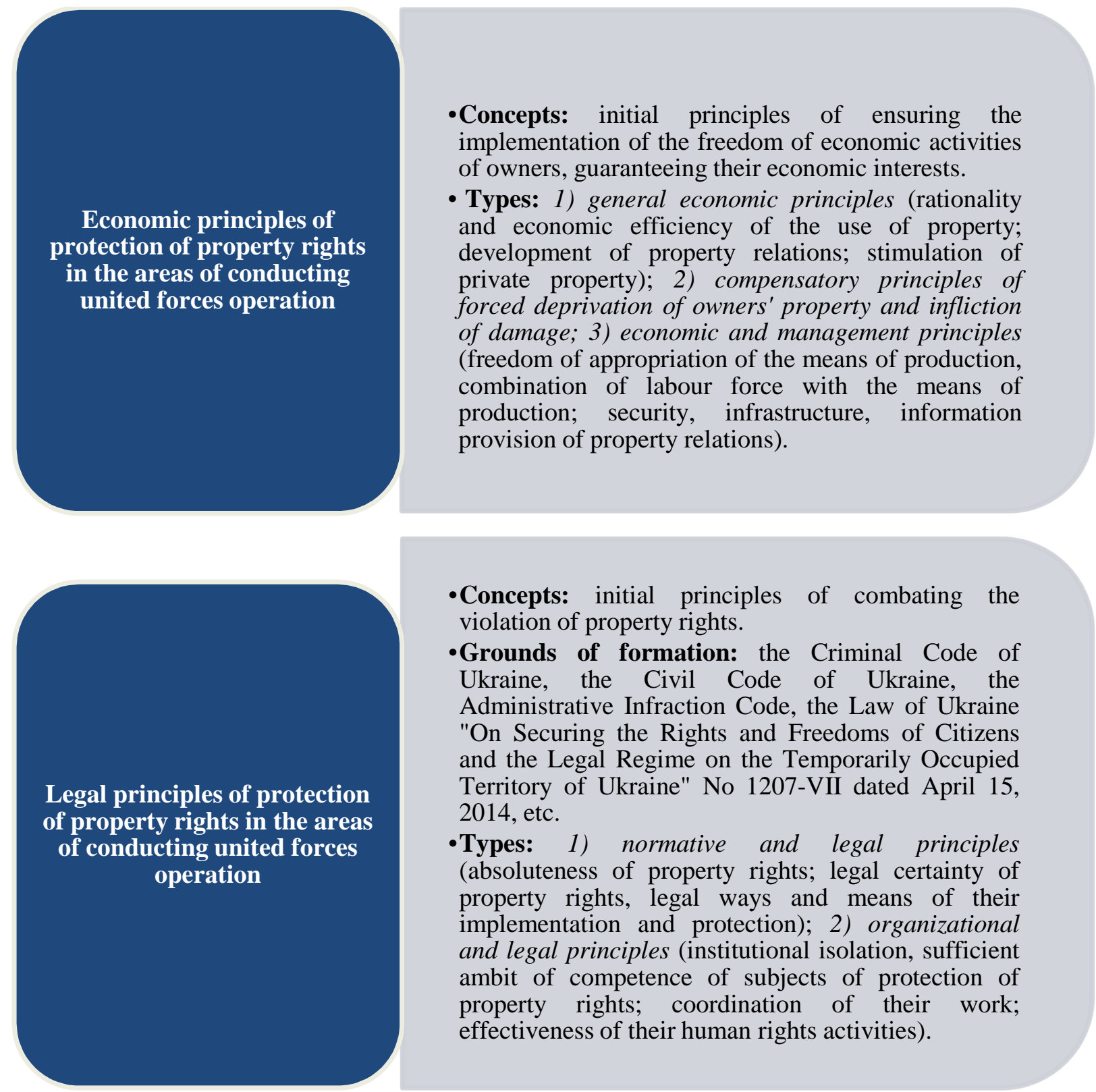

- Concepts: initial principles of combating the violation of property rights.

- Grounds of formation: the Criminal Code of Ukraine, the Civil Code of Ukraine, the Administrative Infraction Code, the Law of Ukraine "On Securing the Rights and Freedoms of Citizens and the Legal Regime on the Temporarily Occupied Territory of Ukraine" No 1207-VII dated April 15, 2014, etc.

-Types: 1) normative and legal principles (absoluteness of property rights; legal certainty of property rights, legal ways and means of their implementation and protection); 2) organizational and legal principles (institutional isolation, sufficient ambit of competence of subjects of protection of property rights; coordination of their work; effectiveness of their human rights activities).

Source: Compiled by the authors

In accordance with the Comprehensive National Programme for Support, Social Adaptation and Reintegration of Citizens of Ukraine Internally Displaced from the Temporarily Occupied Territory of Ukraine and ATO Conduct Area to Other Regions of Ukraine for the period until 2017, approved by the resolution of the Cabinet of Ministers of Ukraine No. 1094 dated December 16, 2015, the task for the period of 2016-2017 was ensuring the right of internally displaced persons to housing.However, at present, the procedure for the implementation of this right is not defined in the legislation. Among the problems of the citizens of Ukraine internally displaced from the temporarily occupied territory of Ukraine and ATOconduct area to other regions of Ukraine, this program determined the lack of information about the amount of damages (property damage) caused to displaced persons in course of hostilities and the mechanism of their compensation. The program declared a commitment to eliminate this problem until 2017. Despite the declared commitment, today there is no normative and legal act, 
which would have determined the mechanism of compensatory payments for destroyed, damaged housing, property expropriated in connection with the implementation of mobilization measures or there is no body, which would have carried out an assessment of the damage. The Verkhovna Rada of Ukraine registered the bill. However, on December 22, 2016, the Verkhovna Rada did not pass it. The alternative bill has not been proposed for consideration.

A great number of citizens consider inefficiency of the activities of public administration concerning the protection of property rights in Donetsk and Luhansk oblasts as an important economic and legal factor that affects the property in terms of UFO and ATO. The biggest problem is the lack of a special body of the protection of property rights of citizens affected as a result of conducting UFO and ATO.The creation of such a body of state power would allow beginning a detailed assessment of the damage caused to the property of citizens, the development of the concept of a phased return of citizens left for other countries because of conducting united forces operationto the previous place of residence. Achievement of this aim should be accomplished through the development of the system of compensatory payments for violations of property rights, the establishment of the comprehensive procedure for obtaining affordable housing.The experience of forming safeguards for the protection of property rights of persons affected by the Nagorno-Karabakh armed conflict should become the example for Ukraine. As a result of the implementation of the State programme on refugees and forced migrants in Nagorno-Karabakh, over 180000 internally displaced persons and refugees moved into more than 80 specially constructed settlements [16].

Today, many European countries, the United States and international organizations provide assistance to persons who suffered from conducting united forces operation, and among them: Red Cross Society, Person in Distress, UNICEF, Office of the United Nations High Commissioner for Refugees (UNHCR), Caritas and others. Measures implemented by these international organizations are deprived of coordination with each other and they only partially ensure the protection of property rights. Property rights of people are still not protected due to the lack of a clear mechanism for implementation of the compensatory payments for citizens who lost their housing, a unitary administrative center for coordination of such measures.

Conclusions. In order to reduce migration of the population of Donetsk and Luhansk oblasts, Ukraine should create reliable economic and legal principles of protection of property rights that include the opportunity to possess, use and dispose of property in this region, which is guaranteed by the state due to normative and legal acts, the functioning of public institutions, which can protect this right, the mechanism of compensation for lost, damaged movable and immovable property. Creating effective economic and legal principles of protection of property rights in the areas of conducting united forces operationin Ukraine is connected with a number of important reforms. A special state program of economic integration of the territories affected by conducting united forces operationshould become the economic and legal basis for strengthening the protection of property rights in the areas of conducting united forces operation. It is important to adopt a new program of economic development of Donetsk region, the state program of strengthening the protection of property rights of citizens of Ukraine in Donetsk and Luhansk oblasts. On the model of other countries that have experienced armed conflicts, Ukraine should provide funding for the construction of special settlements in order to return internally displaced persons to abandoned places of habitual residence. It is necessary to establish a mechanism of compensation for damaged or destroyed real estate, plots of land and personal property. It is necessary to create a government body protecting the property rights of persons affected by hostilities, which would include a special commission for assessment of damages incurred as a result of hostilities, determination of the amount of the required compensation, a complex of measures aimed at restoration of the technical conditions of the building structures of ownership, engineering networks and systems. 


\section{REFERENCES (IN LANGUAGE ORIGINAL)}

1. UNHCR's annual Global Trends Report. 2016.URL: http://www.unhcr.org/global-trends-2016media.html (дата звернення: 11.02.2019).2. Звіт Управління Верховного комісара ООН у справах біженців. Управління Верховного комісара ООН у справах біженців, 2017.URL: http://unhcr.org. ua/uk/(дата звернення: 11.02.2019).3. PierreYaredA dynamic theory ofwarand peace. Journal of Economic Theory. 2010. Vol. 145. P. 1921-1950.4. Debraj Ray, Joan Esteban Conflict and Development.Annual Review of Economics. 2017.Vol. 9 P. 263-293. 5. Tanisha M. Fazal Rebellion War Aims \& the Laws of War. Journal of the American Academy of Arts and Sciences. 2017. Vol. 146. P. 71-82.6. Gregory D. Hess, Athanasios Orphanides War and Democracy. Journal of Political Economy. 2001. Vol. 109. P. 776-810.7. Francisco M. Gonzalez Effective property rights, conflict and growth. Journal of Economic Theory. 2007. Vol. 137 P. 127-139. 8. Jordan J. S. Pillage and property. Journal of Economic Theory. 2006. Vol. 131. P. 26-44.9.Гринчук В. Г. Економічні проблеми реформування відносин власності в Україні в світлі зарубіжного досвіду : дис... канд. екон. наук: 08.01.01 «Економічна теорія». Одеса, 2001. 183 с. 10. Галунько В. В. Адміністративно-правова охорона права власності в Україні: дис. ... д-ра юрид. наук: 12.00.07 «Адміністративне право і процес; фінансове право; інформаційне право». Харків, 2009. 483 с. 11. Обліковано 1493057 переселенців.Мінсоцполітики, 2018.URL: http://www.msp. gov.ua/news/14748.html(дата звернення: 11.02.2019).12. Інформація про кількість зареєстрованих ВПО по регіонах, українців, які покинули окуповані території Криму і Донбасу. Мінсоцполітики, 2017.URL: https://ua.112.ua/statji/skilky-sohodniv-ukraini-zareiestrovano-pereselentsiv- $\quad$ z-donbasu-ta-krymu-informatsiia-po-rehionakh-369259.html (дата звернення: 11.02.2019). 13. Які країни прийняли найбільше біженців з Донбасу. Газета «Сегодня». 2017. URL: https://ukr.segodnya. ua/regions/donetsk/stalo-izvestno-kakie-strany-prinyali-bolshe-vsegobezhencev-s-donbassa-1045519.html Управління Верховного комісара ООН у справах біженців. http://unhcr.org.ua/uk/ (дата звернення: 11.02.2019). 14. International property rights index. Property Rights Alliance, 2017. URL: http://www.internationalpropertyrightsindex.org / countries (дата звернення: 11.02.2019). 15. Тематичний звіт «Складне становище цивільного населення, яке постраждало від конфлікту на сході України». Спеціальна моніторингова місія ОБСЄ в Україні, 2017. URL: http://www.nbuviap. gov.ua/index.php?option=com_content\&view= article\&id=2177: vidshkoduvannyazbitkiv-zavdanikh-zhitlu-naselennya-v-zoni-ato\&catid=8\&Itemid=350 (дата звернення: 11.02.2019). 16. Закордонний досвід забезпечення житлом внутрішньо переміщених осіб та компенсації за пошкоджене/ зруйноване житло виконано. Shelter cluster. Технічна робоча група 3 питань житла, землі та майна, 2017. URL: poкyhttps://www.sheltercluster.org/sites/default/files/docs/ foreignexperiencehousingforidps- integrated-ukr_0.pdf (дата звернення: 11.02.2019).

\section{REFERENCES}

1. UNHCR's annual Global Trends Report, 2016.Avalable at:http://www.unhcr.org/global-trends2016-media.html. (accessed 13.02.2019). 2. Zvit Upravlinnya Verxovnogo komisara OON u spravax bizhenciv, 2017. [Office of the United Nations High CommissionerReport].Avalable at:http://unhcr.org.ua/uk/(accessed 13.02.2019). (in Ukr.). 3. PierreYared. A dynamic theory of war and peace. Journal of Economic Theory, 2010, vol. 145, pp. 1921-1950. 4. Debraj Ray, Joan Esteban. Conflict and Development. Annual Review of Economics, 2017, vol. 9, pp. 263-293. 5. Tanisha M. Fazal. Rebellion, War Aims \& the Laws of War. Daedalus. Journal of the American Academy of Arts and Sciences, 2017, vol. 146, pp. 71-82. 6. Gregory D. Hess, Athanasios Orphanides. War and Democracy. Journal of Political Economy, 2001, vol. 109, pp. 776-810. 7. Francisco M. Gonzalez. Effective property rights, conflict and growth. Journal of Economic Theory, 2007, vol. 137, pp. 127-139. 8. Jordan J. S. Pillage and property. Journal of Economic Theory, 2006, vol. 131, pp. 26-44. 9. Gry`nchuk V. G. Ekonomichni problemy reformuvannya vidnosy`n vlasnosti v Ukrayini v svitli zarubizhnogo dosvidu. Dis. kand. ekonom. nauk. [Economic problems of property relations reform in Ukraine in the light of 
foreign experience],Odessa, 2001. 183 p. (in Ukr.). 10. Galun`ko V. V. Administraty vno-pravova oxorona prava vlasnosti $v$ Ukrayini. Dis. kand. yurid. nauk. [Administrative and legal protection of property rights in Ukraine],Kharkiv, 2009. 483 p. (in Ukr.). 11. Oblikovano 1493057 pereselenciv. [1 493 057 migrants have been trained]. Minsoczpolity`ky', 2018. Avalable at:http://www.msp.gov.ua/news/14748.html. (accessed 13.02.2019). (in Ukr.). 12. Informaciya pro kil kist zareyestrovany`x VPO po regionax, ukrayinciv, yaki poky`nuly`okupovani tery toriyi Kry'mu $i$ Donbasu. [Information on registered internally displaced persons by regions and Ukrainians who left the occupied territories of Crimea and Donbass already in 2017]. Minsoczpolity`ky`, 2017. Avalable at:https://ua.112.ua/statji/skilky-sohodni-v-ukraini-zareiestrovano-pereselentsiv-z-donbasu-ta-krymuinformatsiia-po-rehionakh-369259.html. (accessed 13.02.2019). (in Ukr.). 13. Yaki krayiny`pry`jnyaly najbil she bizhenciv z Donbasu. [Which countries have adopted the largest number of refugees from the Donbas]. Gazeta «Segodnya». 2017. Avalable at: https://ukr.segodnya.ua/regions/donetsk/staloizvestno-kakie-strany-prinyali-bolshe-vsego-bezhencevs-donbassa-1045519.html(accessed 13.02.2019). (in Ukr.). 14. International property rights index. Property Rights Alliance, 2017. Avalable at: http://internationalpropertyrightsindex.org /country?s=Ukraine.(accessed 13.02.2019). 15. Tematy`chny`z zvit «Skladne stanovy`shhe cy`vil’nogo naselennya, yake postrazhdalo vid konfliktu na sxodi Ukrayiny»». [Thematic report "The difficult situation of the civilian population affected by the conflict in eastern Ukraine»]. Special`na monitory`ngova misiya OBSYe v Ukrayini, 2017. Avalable at: http://www.nbuviap.gov.ua/index.php?option=com_content\&view= article\&id=2177:vidshkoduvannya-zbitkiv-zavdanikh-zhitlu-naselennya-v-zoni-ato\&catid=8\&Itemid= 350. (accessed 13.02.2019). (inUkr.). 16. Zakordonny'j dosvid zabezpechennya zhy'tlom vnutrishn`operemishheny xosibtakompensaciyizaposhkodzhene/zrujnovanezhy`tlovy konano. [Foreign experience in providing housing for internally displaced persons and compensation for damaged / destroyed housing]. Shelter cluster. Texnichna robocha grupa z py`tan`zh`tla, zemli ta majna, 2017. Avalable at: https://www.sheltercluster.org/sites/default/files/docs/foreignexperiencehousingforidpsintegrated-ukr_0.pdf. (accessed 13.02.2019). (in Ukr.).

Дата надходження: 07.02.2019 р. 